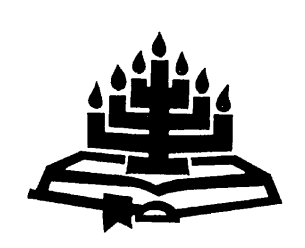

\title{
Probleme rondom die verklaring van die Bybel in die gereformeerde teologie: 'n Christelik-filosofiese besinning
}

\author{
B.J. van der Walt \\ Skool vir Filosofie \\ Potchefstroomkampus \\ Noordwes-Universiteit \\ POTCHEFSTROOM \\ E-pos: hannah@intekom.co.za
}

\begin{abstract}
Problems in interpreting the Bible in reformed theology: a Christian-philosophical reflection

It is becoming evident that previous convictions about the nature of the Bible as well as the ways in which it should be interpreted, are not convincing anymore. The resulting uncertainty is causing division and tension among reformed theologies and churches in South Africa. This Christian-philosophical reflection intends to help clarify some of the issues. A previous article (cf. Van der Walt, 2008d) was focused mainly on a view of Scripture itself, while the present article concentrates on its interpretation. However, to be able to read the Bible correctly, one has to know exactly what kind of book it is - how it is qualified.
\end{abstract}

The first main section, therefore, discusses what it means to view the Bible as a book of faith. The following section provides an overview of the traditional hermeneutical methods, including the most popular among reformed scholars. In the third part attention is given to the "hermeneutical revolultion" since the last part of the previous century. Since not only the ancient Bible text, but also the present-day reader are regarded as important today, one's worldview and philosophy have become vital determining elements in reading Scripture. The last section, therefore, discusses the relationship between worldview and exegesis. As one's worldview influences one's exegesis, one can not deny or try to hide one's worldviewish presuppositions. At the same time, however, one should be aware of the dangers associated with a Christian worldview. Thus, a few 
criteria for judging the correctness of a worldview will be mentioned in conclusion.

\section{Opsomming}

\section{Probleme rondom die verklaring van die Bybel in die gereformeerde teologie: 'n Christelike-filosofiese besinning}

Dit wil lyk asof vroeëre oortuigings oor die aard van die Skrif, asook die maniere waarop dit uitgelê behoort te word, nie meer so vas staan en so oortuigend is nie. Die gevolglike onsekerheid veroorsaak verdeeldheid en selfs spanning onder gereformeerde teoloë en kerke in Suid-Afrika. Die Christelik-filosofiese besinning in hierdie artikel is 'n poging om 'n verheldering ten opsigte van sekere probleme te probeer bied. 'n Vorige artikel (vgl. Van der Walt, 2008d) het veral gefokus op die moontlike bydrae van die reformatoriese filosofie tot 'n Skrifbeskouing. Hierdie artikel sal veral op probleme rondom Skrifverklaring konsentreer. Om die Bybel egter reg te kan lees, moet 'n mens eers weet watter soort boek dit is - hoe dit gekwalifiseerd is.

Die eerste afdeling handel dus oor die betekenis daarvan om die Bybel as 'n geloofsboek te beskou. Die volgende gedeelte bied 'n oorsig oor die tradisionele hermeneutiese metodes, insluitende die mees populêre onder gereformeerde geleerdes. In die derde deel word aandag geskenk aan die "hermeneutiese revolusie" vanaf die laaste gedeelte van die vorige eeu. Aangesien die antieke Bybelteks sowel as die huidige leser van toe af as belangrik beskou word, het 'n mens se lewensvisie en filosofie belangrike, bepalende elemente in die lees van die Skrif geword. Die laaste gedeelte bespreek daarom die verhouding tussen lewensvisie en eksegese. Aangesien 'n mens se lewensvisie jou verklaring van die Bybel beïnvloed kan 'n mens nie jou lewensbeskoulike vooronderstellings ontken of probeer wegsteek nie. Terselfdertyd moet 'n mens egter bewus wees van die gevare verbonde aan 'n Christelike lewensvisie. Daarom word ten slotte 'n paar kriteria genoem om die korrektheid van 'n lewensvisie te help beoordeel.

\section{Inleiding}

In 'n vorige artikel (vgl. Van der Walt, 2008d) is reeds aangetoon dat daar tans nie eenstemmigheid onder Gereformeerde lidmate en teoloë in die Gereformeerde Kerke in Suid-Afrika (GKSA) bestaan oor hoe die Bybel verklaar en toegepas moet word op verskillende aktuele vraagstukke nie. (As voorbeeld hiervoor is homoseksualiteit en die vrou in kerklike ampte genoem.) Vanuit 'n Christelik-filosofiese hoek is oor die volgende besin: die Bybel as 'n goddelikmenslike boek; die Bybel as deel van God se drieërlei openbaring; 
en die Bybel as voorwetenskaplike boek. Die fokus was dus op 'n reformatoriese Skrifbeskouing. Hierdie besinning word nou voortgesit met die bedoeling om op die probleme rondom Skrifverklaring te konsentreer. (Vgl. die kernprobleme onder 1.2.4-1.2.8 in Van der Walt, 2008d.)

In die vorige bydrae (Van der Walt, 2008d) is slegs beklemtoon dat die Bybel 'n goddelik-menslike boek is en dat die twee kante wel onderskei, maar nie geskei mag word nie. Die goddelike kant kan slegs gelowig aanvaar word en nie wetenskaplik bestudeer of deurgrond word nie. Die menslike kant kan egter wel geanaliseer word. Die eerste gedeelte van hierdie artikel probeer hierdie kreatuurlike faset van die Skrif analiseer, aangesien dit bepalend is vir die metodes waarvolgens die Skrif geëksegetiseer behoort te word.

Die opset is dus soos volg: Die eerste afdeling is 'n voortsetting van die besinning oor die aard van die Skrif, in besonder as 'n geloofsboek. Die volgende gedeelte bied 'n oorsig oor die verskeidenheid hermeneutiese metodes en toon aan by watter metodes die voorkeur van gereformeerde teoloë vandag lê. Die derde deel vestig die aandag daarop dat eksegese van die Skrif vandag sy "onskuld" verloor het, omdat nou aanvaar word dat, behalwe die teks ook die konteks (waaronder die huidige leser se lewensvisie en filosofie) 'n rol by die interpretasie van die Bybel speel. Die vraag is of die tradisionele gereformeerde eksegtiese metodes deeglik genoeg met hierdie belangrike wending rekening hou. Die laaste gedeelte bespreek die verhouding tussen lewensvisie en eksegese. 'n Ontkenning of verdoeseling van die eie lewensbeskoulike vooronderstellings (met alle klem op die teks) lei tot 'n dogmatistiese instelling. Daarteenoor kan 'n oorbeklemtoning van die lewensbeskoulike bepaling (met gepaardgaande onderbeklemtoning van die Bybelteks) 'n relativistiese houding tot gevolg hê. Is daar 'n oplossing vir hierdie dilemma?

\section{Die aard van die Bybel - in breë filosofiese perspektief}

God openbaar hom deur die skepping, in woorde ('n boek) en in 'n mens, Jesus Christus. In al drie gevalle is dit God wat openbaar, maar die openbaringsmiddel is iets kreatuurliks. Omdat die skepping struktureel filosofies bestudeer en analiseer kan word, geld dit ook vir die Bybel.

Wanneer die kreatuurlike of menslike kant van die Skrif geanaliseer word, beteken dit nie dat die goddelike kant (dat dit God se Woord 
is, geïnspireer deur die Heilige Gees) ontken word nie. Aangesien daar dikwels in die teologie nie veel meer gesê kan word as dat die Bybel die ewige Woord van God is nie, is hierdie filosofiese, strukturele analise belangrik. By hierdie analise word gesteun op vorige navorsing wat alreeds elders gepubliseer is (vgl. Van der Walt, 2008c).

\subsection{Die multidimensionele karakter van die Bybel}

In die reformatoriese filosofie vind 'n ontleding van die skepping gewoonlik plaas deur middel van 'n verskeidenheid modaliteite of aspekte van die werklikheid. (Vgl. Van der Walt, 2006:142-152 vir 'n oorsig oor die modaliteiteleer.) Die volgende vyftien modaliteite (van die eenvoudigste tot mees gekompliseerde) kan onderskei word: die aritmetiese, ruimtelike, kinematiese, fisiese, biotiese, psigiese, logiese, historiese, linguale, sosiale, ekonomiese, estetiese, juridiese, etiese en pistiese (geloof) aspekte.

Toegepas op die Skrif, beteken bogenoemde dat dit (as iets kreatuurliks) al vyftien fasette deel. Enkele voorbeelde wat die Bybel vertoon, is die volgende:

- 'n fisiese kant, want dit is met ink op perkament/papier geskryf/ gedruk;

- 'n historiese kant, omdat dit vertel wat God in die geskiedenis gedoen het;

- 'n logiese faset: dit is verstaanbaar;

- 'n linguale faset: dit is eers mondelings oorgedra en later in die oorspronklike tale op skrif gestel en vandag in baie tale vertaal;

- 'n ekonomiese aspek - dit kan gekoop/verkoop word;

- 'n juridiese aspek - 'n mens het eiendomsreg op jou eie Bybel;

- 'n morele aspek: dit bied riglyne hoe 'n mens eties reg kan leef.

Die Skrif het wel aan al die bogenoemde fasette deel, maar dit word deur die heel laaste, die modaliteit van geloof, gekwalifiseer. Die geloof "kleur" al die ander aspekte, omdat al die ander lewensfasette in die geloof terugkeer. Dit word in die reformatoriese filosofie analogieë genoem. Hier volg enkele voorbeelde van die analogieë: 


$\begin{array}{ll}\text { aritmetiese } & - \text { die term "Drie-eenheid" } \\ \text { ruimtelike } & - \text { God se nabyheid/alomteenwoordigheid } \\ \text { fisiese } & - \text { geloofskrag } \\ \text { biotiese } & - \text { geloofsverval, geloofsgroei of -verdieping } \\ \text { sensitiewe/psigiese } & - \text { geloofsvertroue/-gevoel } \\ \text { logiese/analitiese } & - \text { geloofskennis } \\ \text { historiese } & - \text { verskillende historiese soorte/tipes geloof } \\ \text { linguale } & - \text { tipiese geloofs- en Bybeltaal } \\ \text { sosiale } & - \text { geloofsgemeenskap/-omgang } \\ \text { ekonomiese } & - \text { geloofsoffervaardigheid } \\ \text { estetiese } & - \text { geloofsharmonie/-eenheid } \\ \text { juridiese } & - \text { geloofsgehoorsaamheid en Skrifgesag } \\ \text { etiese } & - \text { geloofstrou/-volharding }\end{array}$

\subsection{Die Bybel as geloofs-, konfessionele of sekerheidsboek}

Hierdie gedagte van die Bybel as geloofsgekwalifiseerde boek is deur verskillende denkers verder uitgewerk. Die drie belangrikste figure is Sinnema (1975), Spykman (1973a; 1973b; 1985; 1992) en Olthuis $(1976 ; 1979 ; 1987)$. Hulle beskouings word agtereenvolgens saamgevat waaruit ook sal blyk hoe hulle mekaar aangevul het.

\subsubsection{Sinnema se bydrae}

Sinnema (1975) verrig belangrike voorwerk deur aan te toon dat taal nie eenvoudig taal is nie, maar altyd deur een of ander aspek gekwalifiseer word. So is die taal van 'n regsgeding juridies gekwalifiseerd, wetenskaplike taal logies, besigheidstaal ekonomies en omgangstaal tussen mense sosiaal gekwalifiseerd (vgl. Sinnema, 1975:6).

\section{- Geloofstaal}

Om die Bybel reg te verstaan is dit dus noodsaaklik om te weet watter soort taal dit gebruik. Die Bybel gebruik geloofstaal; taal wat deur die pistiese faset gekwalifiseer word. Geloofstaal is nie bonatuurlike taal nie, maar gewone menslike taal wat bloot verskillend as die ander soorte genoemde tale gekwalifiseerd is. Die Bybelse taal is nie dieselfde as wetenskaplike teologiese taal nie. Gewone geloofstaal gee uitdrukking aan 'n bepaalde geloof, terwyl teologiese taal dit wetenskaplik analiseer (vgl. Van der Walt, 2008d, afd. 4.) Sinnema dui dié soort taal aan as certitudinal discourse. 


\section{- Gesagvol oor die hele lewe}

Verder wys Sinnema op die belangrike rol wat die geloofsfaset in die hele lewe van die mens speel. Terugverwysend of retrosiperend (vgl. 2.1 hierbo) na die vroeëre aspekte, integreer die geloof die hele lewe of "kleur" dit. Vooruitwysend is daar nie verdere kreatuurlike aspekte nie. Daarom wys dit bo die skepping uit na die transendente God/god of die mens se laaste sekerheid. Via die geloof het die Skrif dus gesag oor die hele lewe.

In die lig van die sekerheidstaal (certitudinal language) wat die Bybel gebruik, toon Sinnema (1975:22) verder aan dat dit verkeerd is om sekere boeke in die Ou en Nuwe Testament "historiese boeke" te noem. Hulle is volgens hom certitudinal, not historical writings. Die vraag is dus of dit korrek (geldig) is om die Bybel alleen volgens ' $n$ grammaties-historiese metode te bestudeer.

\subsubsection{Spykman se bydrae}

Hierdie reformatoriese denker bou voort op wat reeds by Sinnema gevind is.

\section{- $\quad$ 'n Konfessionele boek}

Hy gebruik nie die woord certitudinal nie, maar eerder confessional om die Bybelse boodskap te kwalifiseer, maar bedoel daarmee dieselfde geloofsaspek as Sinnema. Daarmee wil hy ook aandui dat die Bybel nie primêr 'n politieke, ekonomiese, psigologiese of sosiale boek is nie (vgl. Spykman, 1973a:11). Met "konfessioneel" bedoel Spykman (vgl. 1985:63, 64) nie die mens se subjektiewe ervarings en uitsprake oor God nie. Hy sê uitdruklik (Spykman, 1985:49) die Bybel is die Woord van God in die woorde van menslike taal.

\section{- Voorbeelde}

Volgens Spykman is dit wel moontlik om uit die Bybel iets te wete te kom oor die politieke aspekte van Dawid se regering of die ekonomiese bloei tydens die regering van Salomo. 'n Mens kan ook die apostel Petrus psigologies bestudeer, óf Paulus se sending vanuit 'n taalkundige perspektief bekyk. Dit is maklik, want al hierdie aspekte van die werklikheid is teenwoordig in die Skrif, anders sou die Bybel nie 'n gewone kreatuurlike boek gewees het nie en die geskiedenis van die verlossing nie 'n reële gebeurtenis nie. Al die ander fasette is egter ondergeskik aan die geloofsfaset wat hulle almal kwalifiseer of lei (vgl. Spykman, 1992:130). 


\section{- $\quad$ Meer as net gewone geskiedenis}

Spykman doen veral moeite om aan te toon dat die Bybel nie geskiedenis in die gewone sin van die woord bied nie, maar wel "prophetic history, interpreted history, history with a point" (vgl. byvoorbeeld Spykman, 1973a:11).

Hy verduidelik die soort konfessionele geskiedenis ook met talle voorbeelde uit die Bybel self. Belangrike konings van Israel wat destyds groot invloed gehad het (bv. Omri), word in Konings of Kronieke net in 'n paar verse vermeld, omdat hulle verhouding tot God verkeerd was. Omgekeerd word van polities onbelangrike figure veel meer vertel, omdat hulle in gehoorsaamheid geleef het. Wie dus meer oor spesifieke konings wil weet (vgl. 1 Kon. 14:19, 29), word na die oorspronklike geskrifte (wat die skrywers geraadpleeg het by die opstel van hierdie Bybelboeke) verwys (waaroor ons vandag natuurlik nie meer beskik nie).

Spykman vat sy Skrifbeskouing soos volg saam: "At heart it is not a history book, but a confessing book, a book which confesses, testifies, witnesses, declares, proclaims the mighty acts of God in the history of redemption in a Christocentric way" (Spykman, 1973a:14).

\section{- $\quad$ Tog is geskiedenis belangrik}

Terwyl die een gevaar is dat 'n mens die historiese aspek (of enige ander faset) van die Bybel kan oorbeklemtoon, sodat die leidende geloofsaspek verduister word, kan die omgekeerde ook gebeur. In Bultmann se bekende kerugmatiese teologie bly daar feitlik net 'n boodskap (kerugma) oor sonder historiese gronde. Spykman beklemtoon dus dat die Bybel sowel geskiedenis van die verlossing as geskiedenis van die verlossing is. Die Skrif het ' $n$ historiese basis, dit beklemtoon self dat sy boodskap verankerd is in werklike historiese gebeurtenisse (vgl. Spykman, 1973a:14).

Vervolgens word op 'n derde reformatoriese filosoof gelet wat die voorafgaande insigte van Sinnema en Spykman verder uitgebou het.

\subsubsection{Olthuis se bydrae}

Alhoewel Olthuis sy insigte oor die Skrif tot 'n eie hermeneutiek (vgl. Olthuis, 1987) uitgewerk het, word hier net op sy visie op die Skrif gekonsentreer. 


\section{- $\quad$ 'n Besondere soort boek}

Volgens Olthuis is die Bybel as boek van linguale aard. Daar bestaan egter baie soort boeke, soos 'n telefoonboek, digbundel, regsboek, roman, geskiedenisboek en nog meer. Hulle is verskillende soorte boeke, omdat hulle verskillend gekwalifiseerd is. 'n Regsboek is byvoorbeeld juridies en 'n digbundel esteties van aard. Om 'n roman dus soos 'n geskiedenisboek te lees of 'n telefoonboek soos 'n sosiale register, is 'n ernstige mistasting wat die boek self ook geweld aandoen.

Op soortgelyke wyse word die Bybel misbruik en sy aard aangetas as dit byvoorbeeld primêr as 'n morele handboek, sistematiese teologie, 'n versameling psigologiese gevallestudies, literêre bloemlesing of politieke geskiedenis gelees word.

Volgens Olthuis is dit 'n boek van sekerheid (certainty) - 'n sekerheid wat alleen in die geloof aanvaar en nie redelik bewys kan word nie (vgl. Olthuis, 1976:1). Hy gebruik (vgl. Olthuis, 1976:14) ook ander terme as hy sê: "... the Scriptures rearticulate the Word of God redemptively in a specific focus which we shall call the certainty (or variously the doxological or confessional) focus". Hy gebruik dus terme wat reeds by Sinnema en Spykman aangetref word.

\section{- $\quad$ Voorbeelde uit die Skrif}

Enkele van die voorbeelde wat Olthuis bied, word kortliks genoem, omdat dit sy visie op die Skrif duideliker kan maak.

As in Matteus 6:26 staan dat God die voëls van die hemel kos gee, is dit nie 'n ontkenning van die feit dat hulle self kos moet soek nie. Dit wil die lesers oortuig dat God net so vir hulle ook sal sorg en hulle hul dus nie oor kos en klere hoef te bekommer nie.

Wanneer Elisabet in haar swangerskap sê dat dit die Here is wat dit aan haar gedoen het (Luk. 1:25) beteken dit nie dat sy die geslagtelike en biologiese aspekte van haar verwagting ontken nie. In die laaste instansie ontvang 'n mens egter kinders as geskenk van die Here.

Psalm 127:1, wat sê dat bouers tevergeefs werk as die Here 'n huis nie bou nie, ontken nie dat om 'n huis te bou geld, harde werk, sand, stene en nog baie meer dinge vereis nie. Soos al die ander gedeeltes in die Skrif, is die fokus anders. In hierdie geval wil dit bely en verkondig dat bouwerk wat nie in gehoorsaamheid en met die seën van die Here gedoen word nie, nie sal standhou nie. 
Naomi en Abimeleg se emigrasie na Moab (vgl. Rut 1:1-5) is in die Bybel nie 'n blote ekonomies-politiese aangeleentheid nie. Die konfessionele of sekerheidsdimensie word beklemtoon: hulle ongeloof dat die Here nie in hulle eie land vir hulle sal sorg nie.

Net so is die inname van Kanaän (vgl. Num. 13; 14) in die Skrif veel meer as 'n blote militêre operasie - dit was 'n saak van geloof of ongeloof in God.

\section{- $\quad$ Voordele van so 'n visie op die Skrif}

Om die Bybel op hierdie wyse te lees, hou talle voordele in: Dit is op die geloof gevestig om dit te bou, (vgl. Olthuis, 1987:84) - iets waartoe blote literêre of historiese metodes nie in staat is nie; Ten spyte van die groot verskeidenheid literêre vorms (genres) en historiese kontekste, gee die oorheersende fokus op 'n mens se laaste geloofsekerheid ook eenheid aan die Bybel (vgl. Olthuis, 1987:86); Hierdie visie maak dit ook moontlik om sowel die goddelike as menslike kant van die Skrif volledig te erken (Olthuis, 1987:87); Wanneer die geloofsaspek op dié wyse kwalifiserend optree, word die Bybelse boodskap volgens Olthuis ook nie beperk nie (bv. tot iets geesteliks of bonatuurliks wat die res van die werklikheid minag of ontken). Dit word slegs gekanaliseer. Soos reeds by Sinnema aangetoon, speel geloof 'n integrerende rol in die hele lewe van die mens. Via sy certitudinal dimension het die Skrif gesag oor die totale menslike bestaan (vgl. Olthuis, 1979:82). Dit hoef nie deur middel van allerlei hermeneutiese metodes relevant gemáák te word nie. Dit ontsluit ook die hele lewe in die lig van die transendente.

\section{- 'n Uitsluitlike grammaties-historiese benadering is onvoldoende}

Olthuis (1979:82; 1987:44) kan nie slegs die historiese of grammatiese metodes van Bybellees aanvaar nie, omdat dié twee soorte hermeneutieke alleen nie volle reg aan die Skrif as 'n geloofsboek van laaste sekerheid (ultimate certainty) kan laat geskied nie.

Nog belangriker: indien die Bybel gewone letterkunde of geskiedenis was, kon dit nie vir die hele lewe gesagsvol en relevant wees nie. (Onder 2.1 is aangetoon dat die historiese en linguale heelwat "laer" op die leer van modaliteite of aspekte van die werklikheid lê. Hulle beklee nie die leidende of hoogste plek van die pistiese faset nie.) 


\subsubsection{Dieselfde perspektiewe by ander reformatoriese denkers}

Die gedagte dat die Bybel 'n geloofsboek is, word ook deur veel meer Christelike filosowe ondersteun. Hart (1989:137) sê byvoorbeeld: "The Bible is a book of faith, written in faith, to be read in faith, to be embodied in faith". Troost (2004:133) skryf dat die Bybel nie taalkundig of histories nie, maar pisties gekwalifiseerd is en sê dan (p. 134): "In haar volop menselijk, historisch en talig gewaad, blijft de bijbeltekst een typisch geloofsmatig karakter behouden."

\subsubsection{Gevolgtrekking}

Uit die voorafgaande uiteensetting van die standpunte van Sinnema, Spykman, Olthuis en andere is dit duidelik dat die reformatoriese filosofie in staat is om met behulp van sy leer van 'n verskeidenheid modaliteite die unieke aard van die Skrif te verduidelik. Teoloë volstaan dikwels daarmee deur net te sê die Bybel is die ewige, altydgeldende Woord van God, deur die Heilige Gees geïnspireer. Daarteenoor kan 'n Christelike filosofie ten minste vyftien fasette (aan die menslike kant) van die Bybel aantoon.

Die filosofiese analise van die multidimensionele, kreatuurlike kant van die Woord van God toon ook dat dit vanuit 'n verskeidenheid hoeke, en nie net volgens een of twee metodes nie, kan en behoort gelees te word. Elke metode sal egter rekening moet hou met die feit dat die Bybel 'n pisties gekwalifiseerde geloofsboek is.

Aangesien voldoende refleksie gebied is oor 'n filosofies-verrykte Skrifbeskouing, kan verder gefokus word op hoe die Bybel gelees behoort te word - op 'n geldige Skrifverklaring.

\section{3. 'n Vlugtige oorsig oor die belangrikste hermeneutiese metodes}

Hierdie vinnige oorsig (vgl. Van der Walt, 2008c) se bedoeling is nie om elke metode volledig te behandel en te beoordeel nie. Dit wil bloot aantoon dat die Bybel reeds uit 'n verskeidenheid hoeke benader en gelees is. Verskillende Skrifbeskouings lei tot verskillende Skrifinterpretasies. Die vlugtige oorsig plaas ook die metodes wat gereformeerdes in Suid-Afrika graag volg binne 'n breër agtergrond. Sonder om weer daarop in te gaan, gaan die skrywer ook daarvan uit dat die Bybel gelowig en biddend om die leiding van die Heilige Gees, en nie individualisties nie, maar sáám deur gelowiges verstaan kan word. 


\subsection{Gangbare metodes}

Hoewel hulle dikwels oorvleuel, kan die volgende sewe meer populêre en ook wetenskaplik-hermeneutiese metodes onderskei word. (Vir besonderhede asook waardevolle kritiek op elkeen, vgl. byvoorbeeld Greidanus, 1988; Olthuis, 1976; 1979 en 1987; Seerveld, 2003; Spykman, 1973b en 1985 en Van der Walt, 2006:22-88. Die ouere metodes vanaf Origines tot by Luther word behandel deur Chau, 1995. Greijdanus, 1946:146 e.v. se oorsig gaan tot by Bultmann.)

\subsubsection{Die allegoriese metode}

Dit is een van die oudste metodes in die geskiedenis van die Jodendom (bv. Philo van Aleksandrië) en van die Christendom (bv. Origenes). Hierdeur word gepoog om agter die letterlike betekenis van 'n Skrifgedeelte na die "ware" of "diepere" betekenis daarvan te soek. (Vgl. Van der Walt, 2006:82, 83 vir voorbeelde van hoe Christus se gelykenisse asook die boek Hooglied allegories uitgelê is.) Behalwe hierdie allegoriese metode (sake wat 'n mens moet glo), is gedurende die Middeleeue ook die letterlike betekenis (dit wat sê wat gebeur het), die morele betekenis (dinge wat 'n mens moet doen) en die anagogiese betekenis (dit waarheen jy op pad moet wees) op die Bybel toegepas. Dit word selfs vandag nog deur predikers gebruik.

Die metode het wel aangevoel dat die Bybel 'n unieke boek is en dus anders as 'n gewone geskrif gelees behoort te word. Ongelukkig het dit daartoe gelei dat die leser sy eie gedagtes in die Skrif ingelees het (eisegese) eerder as wat daar uitleg (eksegese) van die Woord van God self plaasgevind het. Bowendien, hiervolgens kan net die teologies-ingewydes die "dieper" betekenis uit die Skrif haal.

\subsubsection{Die spiritualiserende metode}

Dit gebeur wanneer lesers die basiese, historiese en aardse dinge waaroor ' $n$ betrokke Skrifgedeelte handel, ignoreer ten gunste van 'n "geestelike" analogie. Die werklike verhaal van Josef in die put (Gen. 37:24) word byvoorbeeld as troos gebruik vir hedendaagse lesers wat "geestelik in 'n put sit". Die verhaal in Markus 4:35-41 (Jesus maak die storm stil) word ook soms verspiritualiseer tot "storms op ons lewensee". Hoewel dit baie maklik kan wees om die Bybel so relevant te probeer maak, kom dit eerder op 'n verdraaiing of verwringing as op 'n verklaring neer. 


\subsubsection{Die ensiklopediserende metode}

Terwyl die voorafgaande metode te min van die Bybel verwag het, verwag hierdie metode te veel daarvan. Dit maak van die Woord ' $n$ ensiklopedie wat inligting oor alles en nog wat bied en antwoorde op elke moontlike probleem sou verskaf. Christelike wetenskaplikes beskou die Bybel as 'n handboek vir byvoorbeeld die geologie, landbou, astronomie, politiek, opvoedkunde en nog meer. Op hierdie wyse word egter aan die Bybel vrae gestel wat nie bedoel was om beantwoord te word nie - die Bybel word oorvra. Die Bybel is nie ' $n$ wetenskaplike handboek nie, maar in voorwetenskaplike, alledaagse taal geskryf en vir opbou in die geloof bedoel (vgl. Van der Walt, 2008d, afd. 4).

\subsubsection{Die moraliserende metode}

In hierdie geval word 'n Skrifgedeelte tot 'n simplistiese, moralistiese program van moets en moenies omskep. Dit is 'n baie eenvoudige en daarom populêre manier om die lewensgeskiedenisse van Bybelfigure te lees en daaroor te preek. Hulle deugde word as motivering en hulle ondeugde as waarskuwing vir die huidige lesers of luisteraars voorgehou. Voorbeelde hiervan is die wêreldsheid van Lot, die geloof van Abraham, die hardkoppigheid van Moses, ensovoorts. (Vgl. Greidanus, 1988:116-118, 161 e.v. en 175-181; Spykman, 1985:53-61; Seerveld, 2003:22-28 en Van der Walt, 2006:83, 84 vir talle voorbeelde sowel as grondige kritiek op hierdie metode.) Die belangrikste om hier te noem is dat so ' $n$ visie die Bybel reduseer of vermink tot 'n morele (slegs één faset van die lewe) geskrif en die aard en betekenis daarvan grootliks vereng. Uit die voorafgaande het reeds geblyk dat die Woord 'n veel wyer, lewensomvattende, kosmiese betekenis het (vgl. ook Van der Walt, 2009a).

\subsubsection{Die histories-kritiese metode}

Die histories-kritiese hermeneutiek benader die Bybel as 'n versameling gewone historiese dokumente en probeer volgens 'n positivistiese wetenskapsidee vasstel hoe en wanneer die verskillende Bybelgedeeltes ontstaan het en of hulle as histories betroubaar beskou kan word. Wonderverhale word meestal verwerp. (Vir deeglike kritiek op, maar ook waardering vir hierdie metode, vgl. Seerveld, 2003:29-34 en Poythress, 1988:18 e.v.) Greidanus (1988:2530) merk tereg op dat, hoewel die metode belangrike bydraes opgelewer het, dit die Skrif vanuit 'n vreemde lewensvisie benader en tot groot onsekerheid by gelowiges lei. Soos reeds hierbo duidelik 
gestel, is die Bybel die Woord van God al vertel dit 'n historiese verhaal (vgl. ook Van der Walt, 2009b).

\subsubsection{Die dogmatiese metode}

Hierdie metode was en is nogal populêr onder evangeliese en gereformeerde Bybellesers en veral teoloë. Die Woord van God word gelees en bestudeer om sekere proposisies, leerstellings of bepaalde dogmas daaruit af te lei of, omdat dit reeds geglo word, slegs te bevestig.

Die werk van Hart (1989) verduidelik hierdie benadering van die Bybel breedvoerig en bied ook grondige kritiek daarop. Seerveld (2003:34-37) neem hierdie benadering ook deeglik onder die loep. Volgens hom is die grootste gevaar van so 'n metode waarskynlik dat 'n mens se eie vooropgestelde dogmas of lewensvisie jou verhinder om werklik deur die Woord van God gekonfronteer en gekorrigeer te word. Indien jy die Skrif só lees, kyk jy as 't ware in 'n spieël en sien net jou eie beeld in plaas daarvan om deur 'n venster na ander en nuwe dinge te kyk. Hierdie metode impliseer 'n baie eng, reduksionistiese visie op die aard van die Woord - dit word eensydig as 'n leerstellige (logies-analitiese) boek beskou.

\subsubsection{Verskillende literêre metodes}

Gereformeerde teoloë het sedert die Reformasie veral voorkeur gegee aan 'n grammatiese metode, dikwels gekombineerd met 'n historiese metode en vanaf Bernard Weiss in die 19e eeu die grammaties-historiese metode genoem. Die Bybel is as literatuur beskou en die eenvoudige, letterlike betekenis as die belangrikste. Intussen het 'n verskeidenheid literêre metodes van die Skrifstudie ontstaan. Greidanus (1988:51) onderskei byvoorbeeld tussen "source criticism, form criticism, redaction criticism and historical criticism" (vgl. Longman, 1987). Tans is dit populêr om die Skrif met behulp van wetenskappe soos die resepsie-estetika (dit wil sê vanaf die gesigspunt van die huidige lesers), retoriek (redeneerkuns), narratologie (vertelkuns), pragmatiek (effek op die lesers) en nog ander metodes te probeer verstaan. Soms word dit dan tot die enigste sleutel vir die verstaan van die Skrif verhef.

Weereens moet egter aangedui word dat al sodanige metodes nie bloot as waardeloos verwerp mag word nie. Tekskritiek kan byvoorbeeld ' $n$ beter teks tot gevolg hê; historiese kritiek maak ' $n$ mens sensitief vir die historiese konteks; vormkritiek vestig die aandag op die oorspronklike mondelinge tradisie, terwyl redaksionele kritiek 'n 
mens bewus maak van die moontlike redakteurs en die oorspronklike bronne wat hulle kon gebruik het. Nogtans beantwoord al die verskillende literêre metodes nie werklik die vraag na die unieke aard van die Skrif nie - dit is méér as 'n gewone literêre werk.

\subsection{Die gangbare voorkeure van Gereformeerde teoloë}

Die skrywer laat dit aan die lesers self oor om te oordeel of hulle nie dalk nog die prooi is van sommige van die voorafgaande eksegetiese metodes nie.

In die inleidende gedeelte van 'n vorige artikel in In die Skriflig (vgl. Van der Walt, 2008d) is voorbeelde gegee van die hermeneutiese metodes waaraan Gereformeerde teoloë verbonde aan die Teologiese Skool van die GKSA op Potchefstroom voorkeur gee.

Sommige teoloë verkies nog steeds 'n grammatiese (meer literêre) metode à la Grosheide (1929) en Greijdanus (1946) plus nuwere insigte op hierdie gebied. Andere wil daarby ook klem op die openbaringshistoriese en kultuurhistoriese element in hulle eksegese lê, maar nog steeds net van die Bybelteks self. Van die huidige leser se vooronderstellings word net die konfessionele en dogmatiese uitgangspunte erken. Breëre lewensbeskoulike vooronderstellings word wel soms genoem, maar nie werklik in die eksegetiese proses verreken nie. Alle klem lê dus steeds op die teks en dus op 'n grammaties-historiese metode. Die Bybel moet gelees word om te verstaan wat daar geskrywe staan (die grammatiese) en waarom dit op die manier geskrywe is (die historiese). Dit is in ooreenstemming met die ou beginsel dat die Heilige Skrif, omdat dit die Woord van God is, self as beheersende reël vir sy uitleg moet geld (vgl. Greijdanus, 1946:145). Al die reëls vir eksegese moet dus uit die Skrif self afgelei word.

Hierteenoor is aangetoon (vgl. Van der Walt, 2008d) dat teoloë buite Potchefstroom (bv. Snyman) wel die lewensbeskoulike element in die eksegese van die Bybel in berekening wil bring. Die vraag is egter of die wyse waarop dit by hom gebeur nie ten koste van die blywende goddelike gesag van die Skrif geskied nie (vgl. Van Wyk, 2008 se reaksie).

In die voorafgaande (vgl. die slotgedeelte van 2.2.3 hierbo) is ook reeds aangetoon, in die lig van die Bybel as geloofsgekwalifiseerde boek, dat die grammatiese en historiese metodes wel geregverdig is (die Bybel is wel ook 'n literêre en historiese geskrif), maar tog ook hulle beperkings het (vgl. ook Snyman, 2008:31 en Van Deventer, 
2008: 30, 40).Die Skrif vertoon ten minste vyftien dimensies en vereis dus metodes wat beter aan sy multidimensionele aard reg kan laat geskied.

Een van die belangrike leemtes is dat die grammaties-historiese metode teksgebonde is en die huidige leser se rol by eksegese min of meer ignoreer. Die motief mag goed wees, naamlik om die Skrifgesag te "beskerm", maar die metode stam egter uit die tyd toe nog in 'n neutrale beoefening van die wetenskap geglo is onder invloed van die rasionalisme. Dit hou dus nie rekening met die werklike stand van sake van enige soort interpretasie nie. Die werklike situasie is dat dit onmoontlik is om die rol van die huidige leser/eksegeet by die lees van 'n Skrifgedeelte uit te skakel. Silva merk op:

Biblical interpreters in earlier centuries have of course been conscious of the role played by personal bias, but they have simply taken it for granted that such a bias could be overcome. It certainly would not have occurred to them that in the very nature of the case we are incapable of grasping objective reality. (Silva, 1987:112.)

Dit lei tot die volgende afdeling.

\section{Die hermeneutiese revolusie}

Om duidelik te maak waarom hier van 'n "revolusie" gepraat word, word eers iets meer oor die tradisionele metode van eksegese gesê.

\subsection{Die tradisionele eksegetiese benadering}

Soos reeds gesê, lê die klem op die teks volgens die tradisionele benadering, en moet die Skrif self dus die eksegetiese metodes bied (vgl. die titel van Greijdanus se boek "Schriftbeginselen ter Schriftverklaring"). Eksegese geskied volgens 'n aantal eenvoudige reëls (vgl. Greijdanus, 1946:100-145), soos byvoorbeeld die volgende: Skrif moet met Skrif vergelyk word; moeilik begrypbare gedeeltes moet verklaar word in die lig van verstaanbare gedeeltes; oorblywende gedeeltes moet so gelaat word onder die motto non liquet; onderskeid moet gemaak word tussen die ou en nuwe bedeling, tussen verskillende genres, ensovoorts.

Hierdie tradisionele metode (die toepassing van 'n aantal reëls) word wyd gebruik (soos blyk by die inleiding van Van der Walt, 2008d in die geval van Vorster. Nog voorbeelde is: Duvenage (1985); Floor \& Coetzee (1990); Jonker (1977); Stott (1988) en Van Wyk (1989)). 
Vandag word besef dat hierdie reëls wel belangrik is, maar glad nie voldoende nie.

\subsection{Die radikale hermeneutiese wending}

Die nuutste hermeneutiek plaas, in teenstelling met die tradisionele, die aksent nie meer op die teks nie, maar op die huidige leser (vgl. Silva, 1987:7). Dit het 'n hele omwenteling beteken, omdat eksegese nou met 'n baie wyer spektrum faktore rekening moet hou.

\subsubsection{Invloed van die irrasionalisme}

Aangesien Troost $(2004: 126,133,425,429,437$, e.v.) hierdie omwenteling in detail beskryf, word slegs die essensiële hier weergegee. (Vir meer besonderhede kan ook die volgende outeurs geraadpleeg word: Derksen, 1983; Poythress, 1988; Rossouw, 1981; Zuidema, s.a. en 1972.)

Die irrasionalistiese filosofie (van pragmatisme, vitalisme en eksistensiefilosofie) het hierdie draaipunt voorberei. Naugle (2002:253) vat die verskil tussen die vroeëre rasionalistiese denke (ongeveer 1600-1900) en die daaropvolgende irrasionalisme soos volg saam:

In the halcyon days of the Enlightenment, the prejudice against any prejudice reigned supreme. The promotors of this project were concerned about epistemological infection stemming from the germs of personal biased and cultural presuppositions. They sought to apply the antibiotic of objective, scientific rationality to all serious theoretical enterprises in order to produce an uncontaminated form of knowledge characterized by mathematical precision. Despite the herculean efforts of those who promoted this dehumanized epistemological program, the dogma of value-free ways of knowing has recently fallen on hard times.

Die nuwe situasie skets hy soos volg:

The prejudice against prejudice has been recognized as a prejudice, and the self-defeating nature of this aspect of the Enlightenment project has been exposed. In these 'postmodern' times many thinkers have perceived that it is virtually impossible, and indeed not even healthy to attempt to quarentine thought, and to rid all conceptual endeavours of the encroachment of personal and cultural contingencies. (Naugle, 2002:254.) 
Die implikasie hiervan is dat interpretasie altyd kontekstueel beïnvloed is. Silva verduidelik:

To interpret the biblical text ... involves a contextual shift. Even when I seek merely to express what Paul meant, for example, I am constrained to do so in my situation: with English rather than Greek, with modern rather than ancient idioms, with Western nuances rather than Middle Eastern thought forms. In other words, all forms of interpretation necessarily include a measure of contextualization. This point is a little frightening because it appears to relativize Scripture. (Silva, 1987:23.)

'n Verkeerde manier van omgaan met die konteks kan inderdaad gevaarlik wees, omdat dit tot subjektivisme en relativisme kan lei (vgl. die huidige postmodernisme).

\subsection{2 'n Nuwe soort hermeneutiek}

Sedert filosowe soos Heidegger en Gadamer, veral sedert laasgenoemde se epogmakende Wahrheit und Methode (1965), het eksegese sy onskuld en eenvoud verloor. Eksegese kan nie langer net besig wees met wat letterlik in die teks staan en die toepassing van 'n aantal logiese letterkundige reëls nie. Die konteks van die huidige leser het nou 'n nie-ignoreerbare deel van die hermeneutiek geword. Die leser se eie omstandighede en veral sy eie lewensvisie speel 'n beslissende rol daarin.

Op wetenskaplike vlak (teologiese eksegese ingesluit) is die leser se filosofie dus van deurslaggewende betekenis. Wysgerige dissiplines soos 'n werklikheidsbeskouing (ontologie), mensbeskouing (antropologie), kenteorie (epistemologie) en taalfilosofie kan nie geïgnoreer word nie. Tereg sê Troost (2004:129) dat hermeneutiek vir baie teoloë vandag nouliks iets anders as sistematiese filosofie geword het.

\subsubsection{Die verskil tussen die oue en die nuwe}

Die volgende twee aanhalings bring die kontras tussen vroeër en tans duidelik na vore:

Er was een tijd dat alles nog zo eenvoudig leek. Met een grammatica in de ene en een lexicon in de andere hand, een concordantie binnen bereik en gewapend met enige kennis van de bijbelse cultuur en geschiedenis, ging de exegeet naar de tekst toe. Dit exegetische handwerk resulteerde in de vaststelling van de betekenis van de tekst, waarmee vervolgens dogmaticus en homileet aan de slag konden ... Hermeneutiek was een kwestie van het opstellen van een aantal leesregels ... 
Deze tijd ligt voorgoed achter ons. (Peels aangehaal deur Troost, 2004:125.)

Hierteenoor sê Troost na aanleiding van die werk van filosowe soos Heidegger, Gadamer en Dilthey

... dat ons verstaan van teksten niet slechts een kwestie van grammatica en logika is, maar primair ... de zaak van onze volledige werklijkheidsbeleving en -beschouwing, met andere woorden: van onze levensbeschouwlijke en wijsgerige totaliteitsvisie ... de theologische hermeneutiek is veel meer dan de toepassing van vijf of tien regels voor exegese (Troost, 2004:133).

\subsubsection{Geen uitkomkans}

Dit is duidelik dat ook die gereformeerde teologie nie 'n keuse het of dit met hierdie belangrike wending wil rekening hou of nie. Al kan grondige kritiek op die irrasionalistiese en postmodernistiese filosofie vanuit 'n Christelike filosofie en teologie gegee word, het hierdie strominge die aandag op 'n feitlike situasie gevestig wat nie ontken kan word nie. Die vraag is dus nie of die lewensbeskoulik-filosofiese rol van die leser erken word of nie, maar hoe dit moet gebeur. Hoe moet dit gebeur sodat die vroeëre absolutistiese dogmatisme (wat die invloed van die leser en konteks wou ignoreer), sowel as die hedendaagse subjektivistiese relativisme (wat die invloed van konteks en leser oorbeklemtoon), vermy word? Sulke vrae lei tot die laaste afdeling van hierdie ondersoek.

\section{Die verhouding tussen lewensvisie/filosofie en Skrifinterpretasie}

Baie gelowiges is nog steeds van mening dat 'n respekvolle en vroom houding teenoor die Bybel voldoende is om dit reg te verstaan. 'n Mens moet net gelowig die Skrif lees en daarna luister.

'n Mens, of jy dit wil erken of nie, lees egter altyd met 'n gekleurde bril en luister met jou eie ore (vgl. Olthuis, 1979:66). Die letterlike lees van die Bybel is volgens Snyman (2007:83-96) 'n mite. Ook Hart (2006) bied grondige kritiek op die sogenaamde objektiewe lees van die Skrif en beveel eerder 'n verantwoordelike lees aan. Die "gewone" leser se Bybellees word deur sy/haar lewensvisie bepaal en die wetenskaplike teoloog se eksegese word daarbenewens ook deur bepaalde (dikwels onbewuste) filosofiese uitgangspunte gekleur. (Filosofie is die wetenskaplike besinning oor 'n lewensvisie.) 
Wat is die implikasies hiervan? Dit vra eerstens vir 'n verandering van gesindheid.

\subsection{Verandering van gesindheid}

Hierdie gesindheidsverandering hou onder meer die volgende in:

\subsubsection{Openlike erkenning}

Heel eerste moet 'n mens nie probeer om jou lewensbeskoulike interpretasie van die Bybel weg te steek of te ontken nie. Olthuis stel dit soos volg:

Normative exegesis takes place when we are keenly aware of our pre-understandings or vision rather than when we try to hide them. Then we are able to let the Bible text speak in terms of the differences from and similarities with our own prejudices. Without such interaction interpreters easily, often unconsciously, trace their own visions and beliefs onto the text and then read them 'objectively' out of the text. Ironic and paradoxical as it may seem, the more aware we are of the forebeliefs and fore-conceptions of our own visions, the more we are able to do justice to the message of the text. (Olthuis, 1987:29; vgl. ook p. 86, 87.)

\subsubsection{Stel die eie lewensvisie oop vir diskussie}

Olthuis $(1987: 13,32,46)$ beklemtoon dat dit nie sal help om bepaalde Skrifgedeeltes oor en oor te lees (her-eksegetiseer) wanneer Christene van standpunt verskil nie. (Vgl. byvoorbeeld die situasie in die GKSA waar Skriftekste oor die vrou in die kerklike ampte al 30 jaar lank bestudeer word sonder dat konsensus bereik kon word.) Die vraag moet eerder gestel word vanuit watter vooronderstellings die botsende groepe die tekste waarop hulle hul visies grond, lees.

Om die eie lewensvisie eerlik op die tafel te lê, is egter nie maklik nie, want 'n lewensvisie groei oor 'n lang tyd binne 'n bepaalde groep en bevat antwoorde op 'n mens se diepste lewensvrae. Om toe te laat dat dit openlik bespreek word, laat 'n mens dus kwesbaar.

\subsubsection{Die Woord van God as toetssteen}

'n Derde punt van belang is dat in die tweegesprek tussen jou eie lewensvisie en die Skrif, die Skrifboodskap die belangrikste is en die hoogste gesag moet geniet. Die Bybelleser moet altyd daarvoor oop wees dat sy eie lewensvisie deur die Woord van God getoets, geweeg, aangevul, gekorrigeer en selfs bevraagteken mag word. Die 
$x$-straaltoets van die Skrif is die belangrikste om te voorkom dat 'n mens 'n gevangene van jou eie, selfs Christelike, lewensvisie word.

\subsubsection{Gehoorsaamheid}

Die resultaat van 'n mens se Bybellees moet natuurlik ook beklemtoon word. Hart (2006:73) stel dit soos volg:

A crucial test of responsible reading is what happens in our lives as a result of reading the Bible. Failure to act on the text, leaving it as merely grasped in our heads, assented to, and perhaps discussed, means failing to trust the text, since guiding us is what the text intends. Failure to embody its meaning is a form of failing to read the text properly.

Hiermee is egter 'n baie belangrike probleem (vgl. die Inleiding) nog nie opgelos nie.

\subsection{Die kernprobleem}

Oordrewe klem op die teks alleen, terwyl die menslike vooronderstellings van die leser geïgnoreer word, lei maklik tot 'n dogmatistiese instelling; 'n té gemaklike gelykstelling tussen die teks (God se Woord) en hoe die leser dit verstaan. Omgekeerd kan oormatige klem op die konteks of lewensbeskoulike uitgangspunte van die leser subjektivisme en relativisme tot gevolg hê. Dan is hoe ek die teks begryp slegs my eie, persoonlike mening of hoogstens dié van 'n bepaalde groep. In die eerste geval (die absolutistiese visie) word te maklik voorgegee dat dit God self is wat praat; in die tweede geval (die relativistiese standpunt) dat net die mens aan die woord is.

'n Lewensbeskouing is dus nie sonder gevare nie. Vervolgens sal die gevare eers kortliks genoem word. Daarna sal nagegaan word of daar kriteria bestaan om te toets of 'n lewensvisie betroubaar is of nie.

\subsection{Die gevare verbonde aan 'n lewensvisie}

Weens beperkte ruimte (vir meer besonderhede, vgl. Walsh, 2000a; 2000 b asook Van der Walt, 2008a; 2008b) kan die volgende gevare net kortliks vermeld word. Die toets, of en in hoe 'n mate ons gereformeerde denke voor van die gevare geswig het, word aan die leser self oorgelaat. 


\subsubsection{Ontaarding in 'n totalitêre, intellektualistiese sisteem}

Die meeste gevare ontstaan as gevolg van die oordrywing van 'n waarheidsmoment. In die eerste geval is dit waar dat 'n lewensvisie omvattend is. Wanneer 'n mens egter die gevoel kry dat 'n lewensvisie nie meer beweegruimte toelaat nie, nie bevraagteken mag word nie of nie jou eie geloofsgroei bevorder nie - en jy dus 'n gevangene daarvan word - begin rooi waarskuwingsligte flikker. 'n Mens kan 'n sisteem aanleer, maar 'n lewensvisie moet jou hart aangryp. Terwyl 'n sisteem iets tydloos en staties kan wees, is 'n lewensvisie iets histories (vir 'n bepaalde tyd bedoel) en dus dinamies. 'n Lewensvisie mag nooit (af)geslote wees nie, maar moet oop bly vir vernuwing.

Nóú verbonde aan hierdie gevaar is die volgende:

\subsubsection{Aanspraak op universele geldigheid}

Ook hierdie afwyking bevat 'n element van waarheid wat egter oordryf kan word. ' $n$ Mens moet met volle oorgawe in die geldigheid van jou lewensvisie glo. Die gevaar in hierdie geval is dat 'n mens kan dink dat slegs jou eie visie die finale, universele waarheid in pag het. Jy hoef dus nie meer 'n oop oog en oor vir ander visies en stemme "van buite" te hê nie. Dit impliseer egter 'n totale oorskatting van iets wat (as gevolg van ons verduisterde verstand) altyd gebrekkig, onvolmaak, onafgerond en onvoltooid sal bly. Die resultaat is ' $n$ toe of 'n geslote lewensvisie of ideologie. Selfs 'n Christelike lewensvisie wat op God se Woord gegrond is, is nie immuun teen verideologisering nie.

\subsubsection{Selfregverdiging van die invloed/mag van die eie groep/geslag}

Ook in hierdie geval word 'n waarheidselement skeefgetrek. 'n Lewensvisie skep vir mense 'n geordende wêreld waarin hulle veilig kan voel. Dié waarheid ontaard egter in dwaling wanneer dit lei tot isolasie, 'n na-binne gerigtheid en geslotenheid van die lewensbeskoulike groep, 'n laer-trek-mentaliteit, 'n beheptheid met eie suiwerheid. So 'n soort lewensvisie bots met Christene se roeping om tot seën vir ander te wees.

\subsubsection{Irrelevansie vir die hedendaagse kulturele konteks}

Die element van waarheid is dat enige lewensvisie vir 'n bepaalde tyd en omstandigheid bedoel is. Die gevaar is egter dat dit opgesluit kan raak in die tydsomstandighede. Dit gebeur wanneer die ou visie 
net so in nuwe omstandighede gekontinueer word. 'n Eietydse Christelike lewensvisie moet help om die unieke probleme van die hedendaagse kultuur te verstaan en alternatiewe daarop voor te stel. 'n Jonger generasie mag dus nie blote napraters van die lewensvisie van hulle voorgeslagte wees nie. Vroeëre formulerings van 'n Christelike lewensvisie is nie waardeloos nie, maar moet herinterpreteer word om relevant te bly en nie in dooie tradisie te verval nie.

\subsubsection{Verlies aan Bybelse inspirasie en dinamiek}

Hiermee word bedoel dat dit nie meer nodig sou wees om die Woord van God te bestudeer nie, omdat jou lewensvisie reeds volledig die evangelieboodskap sou eggo. Die gevaar is dus dat so 'n verabsoluteerde Christelike lewensvisie die Skrif - God se Woord - die swye oplê in plaas van die omgekeerde, naamlik dat jou lewensvisie voortdurend deur God se openbaring ingelig, geïnspireer en gekorrigeer word om dit van stagnasie te bewaar.

Nóú hieraan verbonde is ook die volgende bedreiging:

\subsubsection{Vervanging van 'n persoonlike verhouding met God}

Die regte relasie is dat 'n mens se verhouding met God tot 'n Bybelse lewensvisie sal aanleiding gee. Ook die omgekeerde, dat 'n lewensvisie wat op God se Woord gegrond is, jou nader aan God self sal bring. Dit is egter rampspoedig om 'n Christelike lewensvisie met die verhouding tot God in Christus te verwar of selfs in die plek van dié verhouding te stel. Dan word 'n lewensvisie 'n doel op sigself, 'n gevaarlike afgod.

\subsubsection{Geslote en oop lewensvisies}

Die les is dus dat dit veel beter is om van die begin af ' $n$ oop lewensvisie in plaas van 'n geslote een te huldig - een wat slegs deur middel van 'n krisis oopgebreek en tot ander insigte gedwing kan word. Geslote lewensvisies is gewoonlik sterk tradisionalisties, het nie 'n besef van alternatiewe nie, glo in die heiligheid van hulle oortuigings en het 'n (abnormale) vrees vir bedreiging van hulle standpunt. Daarteenoor word oop lewensvisies gekenmerk deur 'n geringer klem op tradisie, 'n groter besef en erkenning van ander moontlikhede, dit sakraliseer nie hulle eie insigte nie ('n gesonde besef van relatiwiteit) en is ook nie negatief behep met alles wat nuut of anders is nie. 


\subsection{Maatstawwe vir die beoordeling van lewensvisies}

$\mathrm{Na}$ hierdie vlugtige blik op die moontlike gevare, moet die vraag beantwoord word of die erkenning van die rol van lewensvisies ook by die lees van die Bybel - 'n mens nie aan relativisme uitlewer nie. Bestaan daar enige kriteria vir die beoordeling van lewensvisies, sodat dit 'n geldige deel van 'n nuwe, breër hermeneutiek kan word? Op hierdie gebied sal nog baie werk gedoen moet word. Die volgende "toetse" kan egter genoem word (vgl. ook Colson \& Pearcey, 1999:131 e.v., 243, 323; Walsh \& Middleton, 1984:36-38; Naugle, 2002:327, 340 en Van der Walt, 2008b). Die maatstawwe kan in drie groepe ingedeel word: interne, eksterne en ten slotte transendente toetse.

\subsubsection{Interne toetse (vanuit die lewensvisie self)}

In hierdie verband kan op die volgende gelet word: Is die betrokke lewensvisie omvattend genoeg om van die hele werklikheid rekenskap te gee? Vertoon die onderafdelings van die lewensvisie die nodige samehang? Indien 'n lewensvisie nie omvattend en samehangend is nie, kan dit nie tot 'n holistiese, integrale lewenspraktyk, ook in 'n mens se Skrifuitleg, lei nie.

\subsubsection{Eksterne toetse (vanuit die werklikhede buite die lewensvisie)}

Die volgende vyf kriteria kan onderskei word: openheid, ooreenstemming, normatiwiteit, gebalanseerdheid en leefbaarheid.

- Met openheid word eerstens bedoel dat 'n lewensvisie nie die lewe in sy ryke verskeidenheid mag beknel nie, maar moet ontsluit. Bevorder die uitsluiting van vroue uit kerklike ampte byvoorbeeld werklik die ontsluiting van God se skepping? Dit beteken in die tweede plek dat 'n mens, in die lig van die beperktheid van jou eie lewensvisie, oop moet wees om van ander beskouings te leer.

- Ooreenstemming hou verband met die wedersydse wisselwerking tussen 'n lewensvisie en die werklikheid wat dit probeer weergee. Klop die werklikheid met my lewensvisie daaroor? Omgekeerd: klop my lewensvisie met die werklikheid waarin ek lewe; maak dit sin of bots dit daarmee? Hoe verantwoord 'n mens jouself byvoorbeeld oor die feit dat jou lewensvisie nie vroue in kerklike ampte toelaat nie, terwyl hulle op ander terreine van die Suid-Afrikaanse samelewing leiersposisies mag beklee? 
(Ten spyte van die hermeneutiese sirkel is dit 'n belangrike toets.)

- Met normatiwiteit word bedoel dat elke lewensvisie - ook die nie-Bybelse - nie daaraan kan ontkom om God se ordeninge vir die skepping in norme te positiveer nie. God se wette (wat Rom. 1:20 God se krag en goddelikheid noem) word duidelik in die skepping openbaar, só duidelik dat Paulus (Rom. 2:14, 15) selfs sê dit is in elke mens se hart geskrywe en is deel van sy menswees.

God se wetsorde orden, struktureer en onderhou die skepping. Omgekeerd is die skepping 'n antwoord op hierdie orde. ' $n$ Belangrike komponent van 'n lewensvisie is dus die norme wat dit voorskryf. 'n Mens se lewensvisie is die voortgaande toetsing van die verklarende vermoë van die norme wat jy aanvaar.

In die mate waarin 'n lewensvisie daarin slaag om hierdie universele orde reg te verstaan, sal dit aan die aanhangers daarvan 'n gevoel van sekerheid en geborgenheid gee. Ten spyte van wat die hedendaagse postmoderne, irrasionalistiese relativisme beweer, is lewensvisies nie bloot subjektiewe voorkeur nie. Elke lewensvisie hou op sy eie manier vas aan iets bokant subjektiwiteit, historisiteit en relatiwiteit. Daar is, ten spyte van die verdraaiing wat 'n lewensvisie soms kan meebring, tog 'n lewensorde wat dit probeer weerspieël. Dit beteken egter nie dat 'n mens die teenoorgestelde standpunt van die (rasionalistiese) absolutiste aanvaar nie, naamlik dat ons eie lewensvisie God se skeppingsorde absoluut perfek sou weerspieël, sodat ons eenvoudig 'n gelykaanteken kan plaas tussen God se wette en ons verstaan van die wette.

Die toets vir elke lewensvisie is dus: in hoe 'n mate gee dit hierdie orde reg en volledig weer? Omdat God se wette bedoel is om die lewe in sy volle rykdom te beleef (Joh. 10:10), kan allerlei soorte lyding 'n aanduiding wees ("rooi ligte") dat 'n mens God se skeppingsordeninge verkeerd verstaan en positiveer. (Die kwessie van vroue in kerklike ampte in die GKSA sou weer as voorbeeld kon dien.) Groen ligte daarenteen is wanneer vreugde, vrede en heil (sjaloom) ervaar word.

- Gebalanseerdheid vestig die aandag daarop dat die werklikheid 'n groot verskeidenheid - ten minste vyftien - fasette vertoon (vgl. 2.1 hierbo). Om 'n werklikheidsvisie te wees, moet 'n lewensvisie op gebalanseerde wyse elkeen van hierdie aspekte tot hulle reg laat kom. Talle lewensvisies oorbeklemtoon egter een 
(of meer) van die fasette en probeer die ander fasette dan daaruit verklaar (die verskynsel van reduksie). So 'n verabsolutering lei tot -ismes wat nie betroubare lewensvisies is nie. (Manlike seksisme is 'n eeu oue voorbeeld - wat nie beteken dat vroulike seksisme meer aanvaarbaar sou wees nie. Drie ander hedendaagse voorbeelde van sulke -ismes is scientisme, tegnisisme en ekonomisme.)

- Leefbaarheid as toets wil die aandag daarop vestig dat 'n lewensvisie op 'n bepaalde soort lewenswandel behoort uit te loop. Die vraag is of die voorstanders van 'n lewensvisie ook bereid is om dit tot in sy finale konsekwensies uit te leef. Dit hang natuurlik van die sinvolheid van die lewensvisie af. In baie gevalle waar mense byvoorbeeld 'n seksistiese, evolusionistiese, scientistiese of ekonomistiese lewensvisie huldig, vind 'n mens dat hulle terugdeins vir die uiteindelike gevolge van hulle eie lewensvisie. Hulle vlug in een of ander uitweg wat met hulle eie lewensbeskoulike uitgangspunte bots. Evolusioniste kan byvoorbeeld 'n irrasionele sprong uit hulle onhoudbare naturalistiese lewensvisie probeer maak na iets soos liefde en verantwoordelikheid. Manlike chauvinisme kan afgewater word, sodat vroue ten minste as diakens aanvaarbaar is.

\subsubsection{Transendente toets}

Tot sover is interne en eksterne kriteria genoem. Daar is na die lewensvisie self en na die werklikheid wat die wil weergee, gekyk. Hierdie laaste toets word gedoen van die kant van die geloof en openbaring van God. Al die voorafgaande toetse is wel aanduidings vir die betroubaarheid van 'n lewensvisie, maar in die laaste instansie beroep 'n mens jou op jou geloof, wat op openbaring (iets buite jouself) gegrond is. In die geval van 'n Christelike lewensvisie is die Bron van die openbaring buitekosmies of transendent, naamlik God wat sy openbaring in die skepping, Skrif en Christus aan die mens gee. Die finale toets in die geval van 'n Christelike lewensvisie moet dus coram Deo, voor die aangesig van God plaasvind. (In die geval van die nie-Christene word aan iets in die skepping, byvoorbeeld die wetenskap, 'n openbarende en dus goddelike karakter toegeken.) Omdat 'n lewensvisie iets voorwetenskapliks van die hart is ('n kardioskoop), kan 'n mens nooit op redelike en ander gronde alleen weet dat jou lewensvisie die korrekte is nie. Wat hier as kriteria aanbeveel word, is dus niks meer as rigtingwysers of hulpmiddels vir die beoordeling van die eie en ander lewensvisies nie. 


\subsubsection{Gevolgtrekking}

Daar bestaan dus wel reëls - al kan hulle nie so maklik soos grammatiese reëls opgespoor en toegepas word nie - om te voorkom dat die lewensbeskoulike oriëntasie van die leser soveel klem ontvang dat die eindproduk van die eksegetiese proses relativisme is. Die probleem (vgl. 5.2 hierbo) is dus wel oplosbaar.

'n Mens hoef nie te kies tussen die uiterstes van óf 'n dogmatistiesrasionalistiese fundamentalisme (die verlening van goddelike status aan jou eie Skrifverstaan), óf subjektivisties-irrasionalistiese relativisme (wat uit die Bybel afgelei kan word, is van blote persoonlikmenslike aard) nie. Teenoor die eerste ekstreem moet erken word dat ons verstaan van die Bybel 'n 100\% menslike saak en dus feilbaar is. Teenoor die tweede uiterste moet egter onthou word dat, al is ons verstaan hoe gebrekkig, dit nogtans met God se Woord te make het. Omdat die Bybel 'n goddelik-menslike boek is, kan die beperkte menslike verstaan tog na die Woord van God wys - ten spyte van die gebrekkige menslike verstaan daarvan.

\section{Terugblik en resultaat}

'n Lang weg is afgelê sodat 'n blik in die truspieël van waarde kan wees om te bepaal waar hierdie ondersoek 'n mens gebring het.

Die pad is begin met ' $n$ filosofiese analise van die kreatuurlike (vir die mens toeganklike kant) van die Bybel as geloofsboek en die implikasies wat dit vir die interpretasie van die Skrif het. Onder andere is bevind dat, as gevolg van sy multidimensionele aard, die grammaties-historiese metode nie ten volle aan die Woord van God reg kan laat geskied nie. Daarom is daarna aandag gegee aan die moderne wending in die hermeneutiek, wat juis alle klem op die leser in plaas van die teks wil lê. Hermeneutiek word in dié nuwe beweging gelykgestel aan lewensvisie en filosofie. Hierdie, myns insiens, oorbeklemtoning het daartoe aanleiding gegee dat vervolgens op die gevare van verideologiseerde lewensvisies gewys moes word en ook na kriteria gesoek moes word om aan te toon dat nie enige lewensvisie aanvaarbaar is nie.

Die gevolgtrekking was dat die waarheidsmomente van sowel 'n rasionalistiese as irrasionalistiese hermeneutiek erken moet word. Maar terselfdertyd is hulle eensydighede verwerp. Die vroeëre rasionalisties-georiënteerde hermeneutieke (op die Skrifteks alleen gefokus) lei maklik tot dogmatisme (fundamentalisme of positivisme). Die kontemporêre irrasionalistiese of postmodernistiese hermeneutieke 
(met die oorwegende klem op die leser) kan maklik in relativisme verval.

Hierdie ondersoek bring 'n mens dus uiteindelik op 'n pad waarin by die ouer grammaties-historiese metode - sonder om dit kritiekloos te aanvaar - ook 'n lewensbeskoulike hermeneutiek in die GKSA erken behoort te word.

Hierdie verryking en verruiming is die beskeie bydrae van die voorafgaande Christelik-filosofiese besinning. Daarmee is allermins probeer om die Bybel "in 'n teoreties-filosofiese hokkie vas te vang". Inteendeel, daar is gepoog om die lig van God se Woord weer met nuwe krag en duidelikheid vir ons eie tyd te laat skyn. Ons word immers deur die Skrif self opgeroep: "Julle sal goed doen as julle in sy lig bly totdat die dag aanbreek en die môrester opkom in julle harte." (2 Pet. 1:19.)

\section{Geraadpleegde bronne}

CHAU, W.S. 1995. The letter and the Spirit: a history of interpretation from Origen to Luther. New York: Peter Lang.

COLSON, C. \& PEARCEY, N. 1999. How now shall we live? Wheaton: Tyndale.

DERKSEN, L.D. 1983. On universal hermeneutics: a study in the philosophy of Hans-Georg Gadamer. Amsterdam: VU Boekhandel.

DUVENAGE, B. 1985. Christelike wetenskap as Woordgebonde wetenskap. Potchefstroom: PU vir $\mathrm{CHO}$.

FLOOR, L. \& COETZEE, J.C. 1990. Die Skrif en die wetenskap. Potchefstroom: $\mathrm{PU}$ vir $\mathrm{CHO}$.

GADAMER, H.-G. 1965. Warheit und Methode: Grundzüge einer philosophishen Hermeneutik. Tübingen: Mohr.

GREIJDANUS, S. 1946. Schriftbeginselen ter Schriftverklaring: een historish overzicht over theorieën en wijzen van Schriftuitlegging. Kampen: Kok.

GREIJDANUS, S. 1988. The modern preacher and the ancient text: interpreting and preaching Biblical literature. Grand Rapids: Eerdmans.

GROSHEIDE, F.W. 1929. Hermeneutiek ten dienste van de bestudering van het Nieuwe Testament. Amsterdan: Van Bottenburg.

HART, H. 1989. Setting our sights by the Morning Star: reflections on the role of the Bible in post-modern times. Toronto: Patmos.

HART, H. 2006. Reading sacred texts. Tydskrif vir Christelike wetenskap, 42(1):65-74.

JONKER, W.D. 1977. Die Bybel en Gods wil vir ons lewe. Kaapstad: NG KerkUitgewers.

LONGMAN, T. 1987. Literary approaches to Biblical interpretation. Grand Rapids: Zondervan.

NAUGLE, D.K. 2002. Worldview: the history of a concept. Grand Rapids: Eerdmans.

OLTHUIS, J.H. 1976. The Word of God and Biblical authority. Potchefstroom: Institute for the Advancement of Calvinism. (Study pamphlet, no. 101.) 
OLTHUIS, J.H. 1979. Towards a certitudinal hermeneutic. (In Kraay, J. \& Tol, A., eds. Hearing and doing: philosophical essays dedicated to H.E. Runner. Toronto: Wedge Publication Foundation. p. 65-86.)

OLTHUIS, J.H. 1987. A hermeneutics of ultimacy: peril or promise? New York: University Press of America.

POYTHRESS, V.S. 1988. Science and hermeneutics: implications of scientific method for Biblical interpretation. Grand Rapids: Zondervan.

ROSSOUW, H.W. 1981. Filosofiese perspektiewe op die hermeneutiese probleem. (In Rossouw, H.W. Wetenskap, interpretasie, wysheid. Port Elizabeth: Universiteit van Port Elizabeth. p. 17-56.)

SEERVELD, C.G. 2003. How to read the Bible to hear God speak: a study in Numbers 22-24. Sioux Center: Dordt College Press.

SILVA, M. 1987. Has the church misread the Bible? The history of interpretation in the light of current issues. Grand Rapids: Zondervan.

SINNEMA, D. 1975. The uniqueness of the language of faith with special reference to the language of Scripture. Toronto: Institute for Christian Studies. (Student paper.)

SNYMAN, G. 2007. Om die Bybel anders te lees: die etiek van Bybellees. Pretoria: Griffel Media.

SNYMAN, G. 2008. Grammaties-historiese benadering is nie omvattend nie. Die Kerkblad, 111(3218):31.

SPYKMAN, G.J. 1973a. Scripture, faith and science. International reformed bulletin, 16(54):19-31.

SPYKMAN, G.J. 1973b. A confessional hermeneutic: alternative to the historical-critical method. Reformed Ecumenical Synod theological bulletin, 1(3):1-14.

SPYKMAN, G.J. 1985. Biblical hermeneutics. (In Spykman, G.J. Spectacles. Biblical perspectives on Christian scholarship. Potchefstroom: PU for CHE. p. 48-69.)

SPYKMAN, G.J. 1992. Reformational theology: a new paradigm for doing dogmatics. Grand Rapids: Eerdmans.

STOTT, J. 1988. Understanding the Bible. London: Scripture Union.

TROOST, A. 2004. Vakfilosofie van de geloofswetenschap: prolegomena van de theologie. Budel: Damon.

VAN DER WALT, B.J. 2006. The liberating message. Potchefstroom: Institute for Contemporary Christianity in Africa.

VAN DER WALT, B.J. 2008a. Die historiese agtergronde van die postmoderne visie op normatiwiteit en op 'n Christelike lewensvisie. Koers, 72(4):549581.

VAN DER WALT, B.J. 2008b. Die gewildheid, geskiedenis, struktuur, waarde en gevare van 'n lewensvisie. Tydskrif vir Christelike wetenskap, 44(1e \& 2e kwartaal):39-64.

VAN DER WALT, B.J. 2008c. How to view and read God's revelation. (In: Van der Walt, B.J. The eye is the lamp of the body: worldviews and their impact. Potchefstroom: Institute for Contemporary Christianity in Africa. p. 13-48.)

VAN DER WALT, B.J. 2008d. Probleme rondom die Bybel in die gereformeerde teologie: die bydrae van 'n Christelike filosofie. In die Skriflig, 42(4):635663.

VAN DER WALT, B.J. 2009a. Die gevare van 'n moralistiese Skrifgebruik. Word gepubliseer in Tydskrif vir Christelike wetenskap, 45. 
VAN DER WALT, B.J. 2009b. Die voor- en nadele van die histories- en literêrkritiese hermeneutiek. Word gepubliseer in Tydskrif vir Christelike wetenskap, 45.

VAN DEVENTER, H. 2008. 'n Wonderende weerwoord. Die Kerkblad, 111(3218):30, 40.

VAN WYK, J.H. 1989. Die Woord is waardevol: 'n dogmatiese besinning oor die reformatoriese Skrifbeskouing. Potchefstroom: $\mathrm{PU}$ vir $\mathrm{CHO}$.

VAN WYK, J.H. 2008. Oor die Bybel, Bybellees en etiek: in gesprek met Gerrie Snyman. In die Skriflig, 42(4):685-708.

WALSH, B.J. 2000a. Transformation: dynamic worldview or oppressive ideology. Toronto: University of Toronto. (Unpublished paper.)

WALSH, B.J. 2000b. Regimes of truth and the rethoric of deceit. Pro Rege, 28(3):10-17.

WALSH, B.J. \& MIDDLETON, J.R. 1984. The transforming vision: shaping a Christian worldview. Downers Grove: InterVarsity.

ZUIDEMA, S.J. s.a. Van Bultmann naar Fuchs. Franeker: Wever.

ZUIDEMA, S.U. 1971. Hermeneutics in contemporary theology. (In Zuidema, S.U. Communication and confrontation. Assen: Van Gorcum. p. 346-376.)

\section{Kernbegrippe:}

Bybel, aard van

filosofie: Christelike

hermeneutiese metodes

lewensvisie, gevare van

lewensvisie, kriteria vir 'n betroubare

\section{Key concepts:}

Bible, nature of

hermeneutical methods

philsophy: Christian

worldview, criteria for a reliable

worldview, dangers of 
